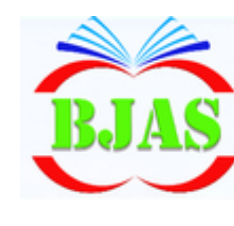

Available online at http://bajas.edu.iq

https://doi.org/10.37077/25200860.2021.34.sp1.5

College of Agriculture, University of Basrah

Basrah Journal

of Agricultural

Sciences

ISSN 1814 - 5868 Basrah J. Agric. Sci., 34(Special Issue 1) , 41--53, 2021

E-ISSN: 2520-0860

\title{
Spatial variability of soil erodibility in response to different agricultural land use at highland farms
}

\author{
Nuraddeen M. Nasidi ${ }^{1,3 *}$, Aimrun Wayayok ${ }^{1,2}$, Ahmad F. Abdullah ${ }^{1,2}$, Muhamad S.M. \\ Kassim $^{1,2}$ \& Nura J. Shanono ${ }^{3}$ \\ ${ }^{1}$ Department of Biological and Agricultural Engineering, Faculty of Engineering, Universiti Putra \\ Malaysia, 43400, UPM Serdang, Selangor, Malaysia.
}

${ }^{2}$ SMART Farming Technology Research Center, Faculty of Engineering, Universiti Putra Malaysia, 43400, UPM Serdang, Selangor, Malaysia.

${ }^{3}$ Department of Agricultural and Environmental Engineering, Faculty of Engineering, Bayero University, Kano. P.M.B. 3011, Kano, Nigeria

\section{*Corresponding author E-mail: nuramnasidi@gmail.com}

Received 19 September 2019; Accepted 8 March 2021; Available online 19 August 2021

\begin{abstract}
This work describes the effect of different agricultural land use on potential soil erodibility $(\mathrm{K})$ at cultivated farming areas in Cameron Highlands. Ordinarily, soils are assigned with $\mathrm{K}$ factors depending on geological properties only which can result into erroneous calculation of soil erosion. This study explores roles of different agricultural land use on the spatial variability of soil erodibility on hilly farms at Cameron Highlands. Soil samples, slopes and spatial locations were collected based on crop types being cultivated. Meanwhile, the land use and type of equipment for each crop are recorded and ranked depending on the degree of soil disturbances. The results showed that, $\mathrm{K}$ values are ranged from 0.0084 to 0.0161 . Shallow-root crops, such as vegetables and flowers have higher $\mathrm{K}$ values due to shallow soil rootzone and frequency of surface operations. However, tea cultivated areas and forests have low $\mathrm{K}$ values, indicating comparably higher ability to resist erosion. Furthermore, the erodibility factor for tea farms shows increasing patterns along the developmental stages while the reverse was found in vegetable farms. Spatial variability of the $\mathrm{K}$ is influenced by various farming operations at different growing stages and the peculiarity of each crop. This work demonstrated that, the soil erodibility factor can be determined considering the crops and stages of development, in addition to geological attributes.
\end{abstract}

Keywords: Cameron highlands, Farming operations, Pedotransfer function, Soil erosion, Tillage.

\section{Introduction}

Soil loss due to water is a major cause of land degradation worldwide, particularly in high rainfall regions coupled with soil disturbance operations (Abdullah et al., 2019). The problem is compounded when practiced on hilly area with considerably less vegetation cover (Abdullah et al., 2019; Dabral et al., 2008; Li et al., 2013; Patowary \& Sarma, 2018). Cameron Highlands is characterized with rampant hilly slopes and favourable climate conditions that allow gainful 


\section{Nasidi et al./ Basrah J. Agric. Sci., 34(Special Issue 1): 41-53, 2021}

agricultural production (Razali et al., 2018). Approximately 31 per cent of precipitation is lost as runoff and soils are at high risk of erosion due to hilly topography, low organic matter, and ineffective agricultural practices (DID, 2012). According to Abdullah et al., (2019), the rate of soil erosion in Cameron highlands ranged from 38 to $73.9 \mathrm{t} \mathrm{ha}^{-1} \mathrm{yr}^{-1}$ which is almost four to seven times the rate of soil erosion considered acceptable in the rest of the world (Fagbohun et al., 2016). Therefore, preventing soil erosion in this type of regions is very important for maintaining soil productivity and general environmental safety.

The measurement of soil erosion is challenging, particularly at a watershed scale, and it is time-consuming, labour intensive and costly (Ostovari et al., 2016). For these factors, soil erosion models have been commonly used to estimate soil losses. The ambiguity of water erosion processes and lack of data are obstacles to the implementation of complex soil erosion prediction models (Diodato et al., 2018). Consequently, the Universal Soil Loss Equation (USLE) which calculates the average annual soil loss due to irrigation and inter-rill erosion, has often been used to estimate soil loss worldwide (Whischmeier \& Smith, 1978). Assessment of spatial variability of is of crucial because of heterogeneity nature of soil and types of soil operation. Soil operation such as agriculture and development for residential purpose usually led to mass deforestation and thus, topsoil becomes vulnerable to soil erosion by water or wind. Although in Malaysia, the wind erosion is completely eliminated due to high precipitation and large vegetation cover (Kaffashi et al., 2015). However, the water erosion is becoming serious particularly at highlands due to the effect of climate change which triggers other environmental problems like landslides and sedimentation of reservoirs (Abdullah et al., 2019).

The soil erodibility ( $\mathrm{K}$ factor) is a parameter that describes the efficacy of raindrop splashing and runoff in dislocating soil particles (Didoné et al., 2017; Nasidi et al., 2020b). Methods for determining $\mathrm{K}$ are classified into several types: soil physiochemical properties, rainfall modelling, wind tunnel experiments and soil erosion experimental plots (Ostovari et al., 2016). The direct measurement of $\mathrm{K}$ using erosion experimental plots is considered the best way to estimate the $\mathrm{K}$ factor and to generate reliable soil loss predictions (Renard et al., 1997). Prevention of soil erosion can be effective when soil erodibility component receives due attention with view to improving soil particle stability against erosion agent. This includes soil organic matter, aggregate sizes, infiltration, surface roughness and clay contents.

Barrow et al. (2005) reported several techniques for sustainable agriculture in Cameron Highlands such as to develop strategies of converting environmentally damaging cultivation to greener and sustainable. For example, tourists could be drawn to agritourism or ecotourism and be paid enough to make sustainable farming viable. Part of sustainable agriculture strategy was to assess the potentials for organic production growth. However, the recent excessive soil erosion and frequent landslides are attributed to unsustainable use of land resources particularly illegal agricultural practices (Abdullah et al., 2019). It was also reported that, there is high risk of erosioninduced landslides in agricultural farms of Cameron Highlands. This indicated that both agricultural operations has a great influence on soil stability against natural disasters (Wayayok et al., 2018). Moreover, Pradhan 


\section{Nasidi et al./ Basrah J. Agric. Sci., 34(Special Issue 1): 41-53, 2021}

et al. (2012) reported that, environmental hazard caused by hill land development are at high rates, especially soil erosion which has occurred in many parts of the hill slopes at Penang Island. This hill slope erosion has led to landslides when not controlled for the last decades. Therefore, assessment of soil ability to withstand erosion effect is crucial particularly at hill slops to avoid landslides and related environmental hazards.

This work aimed to determine soil erodibility variability due to various agricultural land use at farming areas of Cameron Highlands. The study is limited to assess areas cultivating four major crops, i.e., tea, fruits, flower, and vegetable crops, due to inaccessibility of some remote areas

\section{Materials \& Methods}

\section{Description of the Study Location}

Cameron Highlands is located at the main range of Peninsular Malaysia situated on latitude of $4^{\circ} 28^{\prime} \mathrm{N}$, and longitude of $101^{\circ} 23^{\prime} \mathrm{E}$. The average temperatures are $24^{\circ} \mathrm{C}$ and $14^{\circ} \mathrm{C}$ during the day and night, respectively. The elevation ranges between $1070 \mathrm{~m}$ and $1830 \mathrm{~m}$ above mean sea level with average annual precipitation of $2660 \mathrm{~mm}$ (Abdullah et al., 2019; Nasidi et al., 2020a). The region has two distinctive peaks of monthly rainfall. The first peak rainfall amount is normally observed in April while the second with higher rainfall volume occurs around November every year ( Mansor et al., 2015; Ismail et al., 2020; Nasidi et al., 2020a). The highland is regarded as an important source of agricultural produce for the country which occupies an area of 712.18 square kilometers (Fig. 1). The area is surrounded by Kelantan and Perak from north and west respectively and has a potential for growing a wide variety of vegetables, flowers, and other ornamental plants. The climatic condition in the highlands provides opportunity for agricultural activities as the primary business and attracts tourists from all over the world. However, the gradual deterioration of the weather conditions coupled with other environmental issues raised an alarm for investigation (MohdAriffin et al., 2014; Mispan et al., 2015;). The study flow chart is presented in fig. (2).

\section{Soil sampling}

Seventy-two soil samples were collected from agricultural farms that grow either one of the four major crops: Tea, flower, fruits, and vegetables. The soil at the surrounding forest areas of not too far from farms were also sampled because of undisturbed nature of the forest soils. At each selected point, two soil samples were collected using auger and coresampler from top to the lower part of the crop root zone (20\% and $60 \%$ of crop root depth) according to (Nasidi et al., 2014). For example, the depths of soil sampling are 16 $\mathrm{mm}$ and $48 \mathrm{~mm}$ at a farm producing flower whose root depth is $80 \mathrm{~mm}$. This was to give an undisturbed and good representation of soil around each selection point ( ASAE, 2011; Teh, 2011; Dantala et al., 2019). Moreover, two samples were collected for each hectare of farmland making a total of 36 hectares coverage only due to inaccessibility of forest areas. To preserve the soil condition, plastic bags were used to store all the samples and labelled with reference numbers. Furthermore, geographical coordinate of each sampling point was recorded using GPS device. Similarly, the procedures of the soil collection were repeated for middle and late growth stages of the crops at the same locations. 

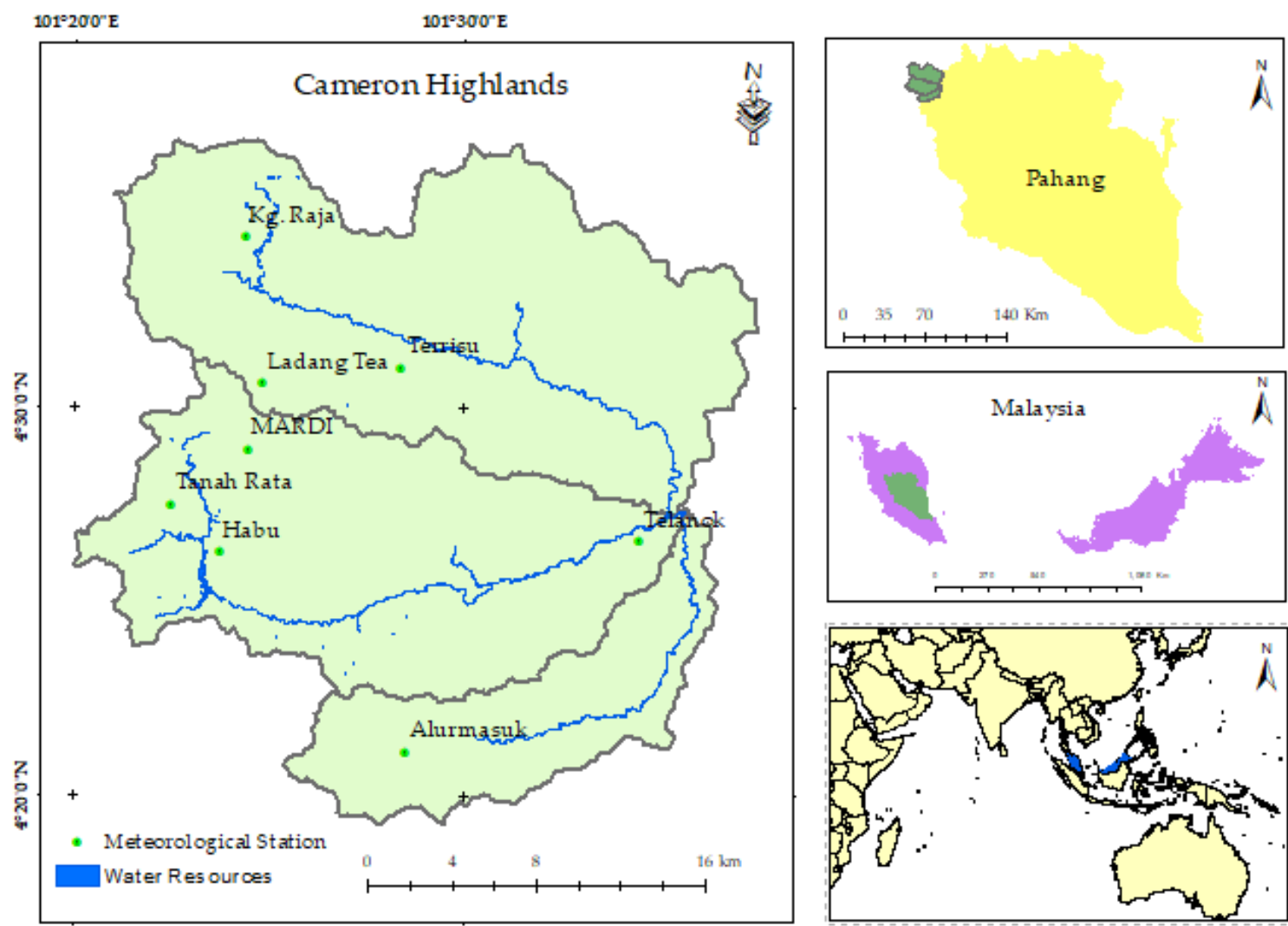

Fig. (1): Catchment area of Cameron Highlands.

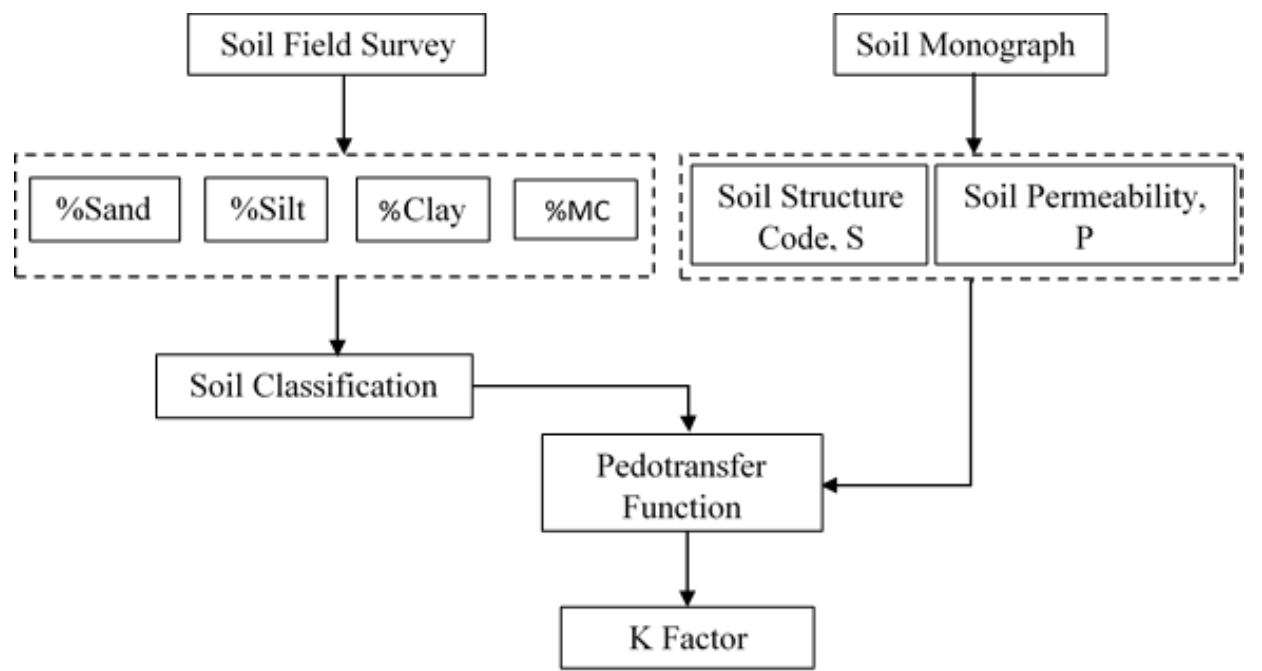

Fig. (2): Study flow chart

The collected soil samples were transported to soil laboratory for analysis at the Department of Biological and Agricultural Engineering, Universiti Putra Malaysia. The investigations were soil particle size analysis, soil organic matter determination, bulk density, and hydrometer test. Firstly, the organic matter content $(\mathrm{OM})$ was determined by placing the soil samples under $105^{\circ} \mathrm{C}$ temperature in ovum for 24 hours. The hydrometer test was used to determine the soil texture, clay, silt, and sand. These results 
Nasidi et al./ Basrah J. Agric. Sci., 34(Special Issue 1): 41-53, 2021

of soil test were then applied to a Pedotransfer model to generate soil erodibility status for each crop farmland. Thereafter, spatial erodibility map was generated using ArcGIS 10.5 software.

\section{Soil Textural Classification}

The soil particles size analysis revealed different textural classes of each sample examined. Table (1) presents the textural classification of the soil samples ranging from coarse to fine particle sizes according to an acceptable ranges (Weil \& Brady, 2016). In this standard, soil with permeability rate of greater $50 \mathrm{~cm} / \mathrm{hr}$ is considered very rapid and regarded as coarse-textured soil. Likewise, soil with permeability less than $5 \mathrm{~cm} \cdot \mathrm{hr}^{-1}$ is slow and regarded as fine-textured soil.

Similarly, soil textural triangle was used to classify the soil into various categories depending on percentages of clay, sand, and silt. This classification was in accordance with standard of American Society of
Agricultural Engineers (ASAE, 2011; Weil \& Brady, 2016). In this study, the classification of each soil sample was based on depending on to their particle's grade sizes as described in the textural triangle. Thereafter, the sampled and classified soils are assigned with cording from Malaysian soil manograph in fig. (3) as presented by (Tew, 1999). This manograph relates textural classification, soil coding and soil permeability rates.

\section{Determination of $\mathbf{K}$ using a Pedotransfer function}

The Pedotransfer function converts one variable to another and the function is used to translate the available data into the required information (Minasny et al., 2008). Although, the direct measurement of $\mathrm{K}$ using erosion plots is the best way to estimate the $\mathrm{K}$ factor and to generate reliable soil loss predictions (Renard et al., 1997).

Table (1) Soil permeability for different textural classes (Weil \& Brady, 2016)

\begin{tabular}{|c|c|c|c|}
\hline $\begin{array}{l}\text { Textural } \\
\text { Class }\end{array}$ & Texture & $\begin{array}{l}\text { Permeability } \\
\text { Rate }\end{array}$ & $\begin{array}{l}\text { Permeability } \\
\text { Class }\end{array}$ \\
\hline \multirow[t]{2}{*}{ Coarse } & gravel, coarse sand, & $>20$ inches $/ \mathrm{hr}$ & Very rapid \\
\hline & sand, loamy sand & $6-20$ inches/hr & Rapid \\
\hline $\begin{array}{l}\text { Moderately } \\
\text { Course }\end{array}$ & $\begin{array}{l}\text { Coarse sandy loam, Sandy } \\
\text { loam, Fine sandy loam }\end{array}$ & $2-6$ inches/hr & $\begin{array}{l}\text { Moderately } \\
\text { rapid }\end{array}$ \\
\hline Medium & $\begin{array}{l}\text { Very fine sandy loam, Loam, } \\
\text { silt loam, silt }\end{array}$ & $0.6-2$ inches $/ \mathrm{hr}$ & Moderate \\
\hline $\begin{array}{l}\text { Moderately } \\
\text { fine }\end{array}$ & $\begin{array}{l}\text { Clay loam, sandy clay loam, silt } \\
\text { clay loam }\end{array}$ & $\begin{array}{l}0.2-0.6 \\
\text { inches } / \mathrm{hr}\end{array}$ & $\begin{array}{l}\text { Moderately } \\
\text { slow }\end{array}$ \\
\hline Fine & $\begin{array}{l}\text { Sandy clay, silt clay, clay } \\
\qquad(<60 \%)\end{array}$ & $\begin{array}{l}0.06-0.2 \\
\text { inches } / \mathrm{hr}\end{array}$ & Slow \\
\hline
\end{tabular}




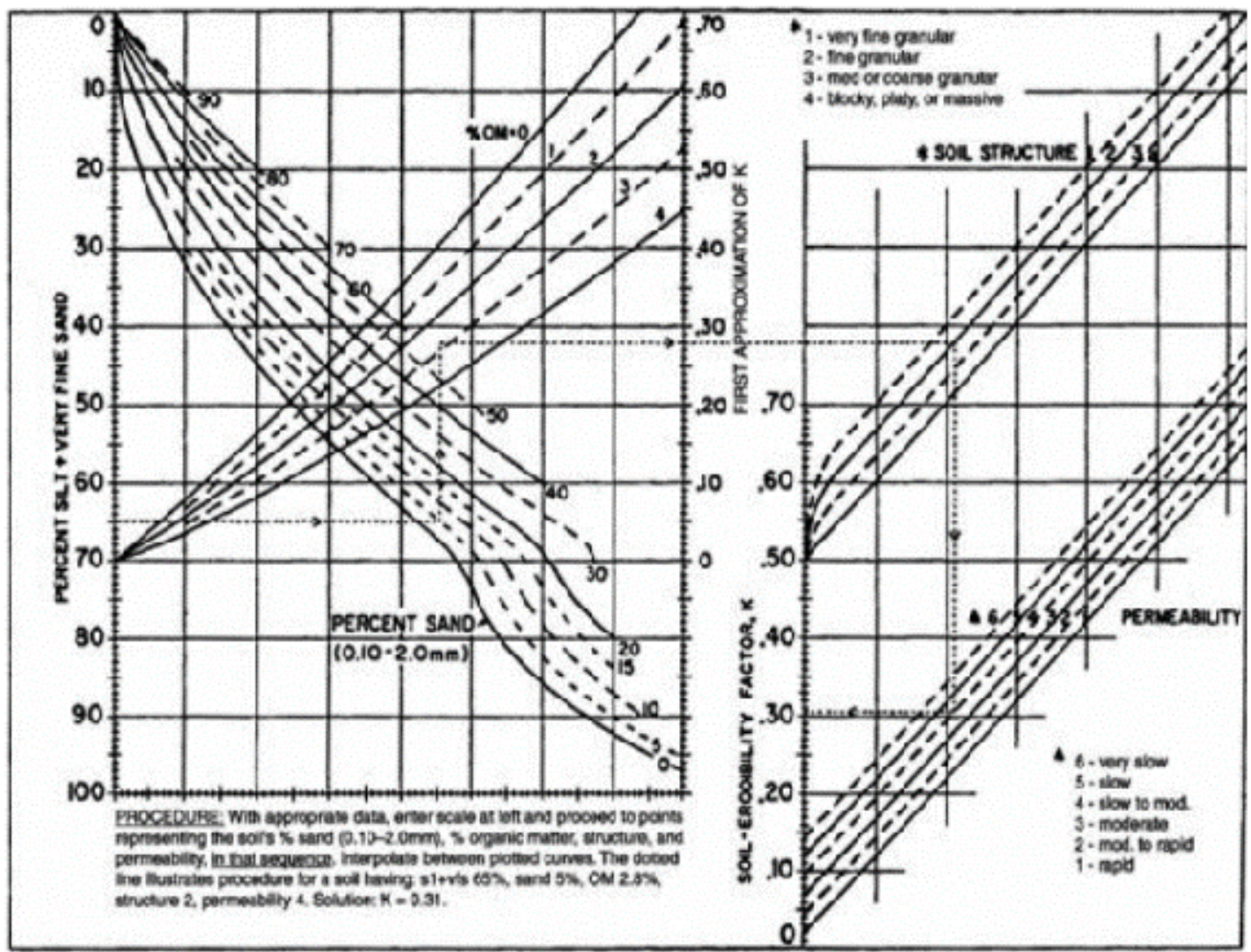

Fig. (3): Soil manograph (Tew, 1999)

However, this Pedotransfer function has been used by many studies and provides promising results of estimation soil erodibility ( Ostovari et al., 2016; Barbosa et al., 2019;). The K-factor was calculated using Pedotransfer function which has been recommended by department of irrigation and drainage Malaysia (DID, 2012; Minasny et al., 2008) as presented in Eq. (1).

$$
\mathrm{K}=\frac{\left[2.1 \times 10^{-4}(12-\mathrm{OM} \%)(\mathrm{N} 1 \times \mathrm{N} 2)^{1.14}+3.25(\mathrm{~S}-2)+(\mathrm{P}-3)\right]}{100}
$$

where, $\mathrm{OM}$ is percentage organic matter, $\mathrm{N}_{1}$ is percentage of silt + very fine sand, $\mathrm{N}_{2}$ is percentage of silt +very fine sand +

\section{Results \& Discussion}

\section{Soil Characteristics.}

Table (2) shows the result of crop type, organic matter, permeability, and textural classification for each sampled soil. Also, the location of sampling areas was identified as Bertam, Ringlet and Lemoi. sand $(0.125-2 \mathrm{~mm}), \mathrm{S}$ is soil structure code and $\mathrm{P}$ is soil permeability class (hydraulic conductivity).

The highest permeability rate of $12.07 \mathrm{~cm}$. $\mathrm{hr}^{-1}$ was found at tea cultivated farm in Bertam region. Furthermore, the soil coding is presented and ranged from 3 to 6 dimensionless values. The result reveals that, most dominant soil textural classes are sandy loamy and clay loam and mostly found along Bertam and Ringlet areas 
(Tew, 1999; ASAE, 2011; Weil \& Brady, 2016). The number of samples for each location were not made equal because not all areas produce the similar crops. For examples, Bertam catchment is dominated by vegetable and fruit production especially at Ringlet area. However, there is lower number of flower farms compared to Telom catchment. Similarly, the tea cultivation is being operated in commercial quantity by Boh Tea Company at both Telom and Bertam catchments.

Table (2) Characteristics of soil parameters at different sampling points

\begin{tabular}{|c|c|c|c|c|c|c|c|}
\hline $\begin{array}{l}\text { Soil } \\
\text { ID }\end{array}$ & $\begin{array}{l}\text { Crop } \\
\text { Type }\end{array}$ & Location & $\begin{array}{c}\text { Area } \\
\text { (ha) }\end{array}$ & $\mathrm{OM}(\%)$ & $\begin{array}{l}\text { Permeabilit } \\
\text { y }(\mathrm{cm} / \mathrm{hr})\end{array}$ & $\begin{array}{l}\text { Soil } \\
\text { Code }\end{array}$ & Textural Class \\
\hline $\mathrm{S} 1$ & Tea & Bertam & 3 & 23.61 & 12.07 & 3 & Sandy loam \\
\hline $\mathrm{S} 2$ & Tea & Ringlet & 3 & 18.72 & 10.08 & 4 & $\begin{array}{l}\text { Fine Sandy } \\
\text { loam }\end{array}$ \\
\hline $\mathrm{S} 3$ & Tea & Lemoi & 0.5 & 19.23 & 10.49 & 4 & Sandy loam \\
\hline $\mathrm{S} 4$ & Tea & Tanah Rata & 1 & 21.44 & 10.69 & 3 & Sandy loam \\
\hline S5 & $\begin{array}{c}\text { Vegetabl } \\
\text { e }\end{array}$ & Bertam & 2 & 17.8 & 5.61 & 4 & Clay loam \\
\hline S6 & $\begin{array}{c}\text { Vegetabl } \\
\mathrm{e}\end{array}$ & Ringlet & 2 & 20.11 & 8.69 & 4 & Sandy loam \\
\hline S7 & $\begin{array}{c}\text { Vegetabl } \\
\mathrm{e}\end{array}$ & Lemoi & 2.5 & 18.3 & 3.99 & 5 & Clay loam \\
\hline S8 & $\begin{array}{c}\text { Vegetabl } \\
\mathrm{e}\end{array}$ & Tanah Rata & 3 & 15.4 & 11.02 & 3 & Sandy loam \\
\hline S9 & Fruit & Bertam & 3 & 15.3 & 2.18 & 6 & Clay loam \\
\hline S10 & Fruit & Ringlet & 2 & 17.75 & 2.74 & 5 & Silt Clay loam \\
\hline $\mathrm{S} 11$ & Fruit & Lemoi & 2.5 & 18.2 & 3.61 & 5 & Silt clay \\
\hline $\mathrm{S} 12$ & Fruit & Tanah Rata & 3 & 16.3 & 5.89 & 4 & Sandy clay \\
\hline S13 & Flower & Bertam & 3 & 14.9 & 9.27 & 4 & Clay loam \\
\hline S14 & Flower & Ringlet & 2 & 17.51 & 7.60 & 4 & Sandy loam \\
\hline S15 & Flower & Lemoi & 1.5 & 15.6 & 7.90 & 4 & Sandy loam \\
\hline S16 & Flower & Tanah Rata & 2 & 14.11 & 10.92 & 3 & $\begin{array}{l}\text { Fine sandy } \\
\text { loam }\end{array}$ \\
\hline
\end{tabular}


*Note: OM - soil organic matter; Soil code, 3 = moderate, 4 = slow to moderate, $5=$ slow, and $6=$ very slow

\section{Soil erodibility based on type of crops cultivated}

In this study, the $\mathrm{K}$ values were computed for each sampled area considering the type of crop cultivated. The survey and soil assessment were conducted based of three levels of crop's growth as: early (two weeks after germination), middle (flowering stage) and after harvesting stages. The soil $\mathrm{K}$ value at fruits farm gave a minimum value of 0.0102 at initial stage of growth which increase drastically to maximum level of 0.0123 at flowering stage. This value reduces to 0.0117 at the late stage when the crop yields were fully harvested. The phenomenon which is found similar at flower farms could be explained by the fact that, most of fruits crop in the study area have low rooting network to balance the effect of soil disturbing operations in the farms during the middle stages of development. This led to the increasing $\mathrm{K}$ values which indicates more soil susceptibility to erosion as crop development continues. The expectation for all the selected crops was that, there is high $\mathrm{K}$ values at the beginning of crop establishment since there were no significant rooting system to give additional soil stability. Also, the level of organic matter is not rich enough as compared to both middle and late developmental stages.

In vegetable farms, the soil $\mathrm{K}$ values increase steadily from initial planting period to the final stage of the crop maturity $(0.0115$ $-0.013)$. This could be understood because vegetables have fragile stems and roots which could not offer a significant support for soil strength. Therefore, the surface modifications of soil due to farming operation will continue to increase susceptibility to erosion. However, in tea plantation the soil erodibility assessment shows a decreasing pattern from initial through middle up to the late developmental stages $(0.0136-0.0112)$. This behavior of the soil could be attributed to the fact that, tea crop requires minimum soil tillage after planting and thus, the increasing root network couple with addition of soil organic matter will continue to reduce $\mathrm{K}$ value. Thus, after reaching the apex at flowering stage, the soil erodibility continues to decrease up to the late growing of the fruit.

In comparison of tea and vegetable farms, the soil $\mathrm{K}$ values behaved in opposite to each other such that, soil at tea farms indicates decreasing pattern from initial to final stages of development while increasing pattern was observed in vegetable farms. Observation shows that, in vegetable farms farmers kept disturbing the topsoil to increase aeration and infiltration throughout the growing period. This operation leads to increasing soil vulnerability of soil erosion especially on hilly farms. Consequently, the soil erodibility increases throughout the farming operation period. Furthermore, similar patterns were observed for fruit and flower farms except that, slightly high $\mathrm{K}$ values were found in flower farms as presented in fig. (4). This can be attributed to the structural similarities of both crops that; they are usually cultivated for short duration without enough times for strong root establishment. However, there is frequent soil operations in fruit and flower cultivation to improve infiltration and aeration to meet crop water requirements). 
Nasidi et al./ Basrah J. Agric. Sci., 34(Special Issue 1): 41-53, 2021

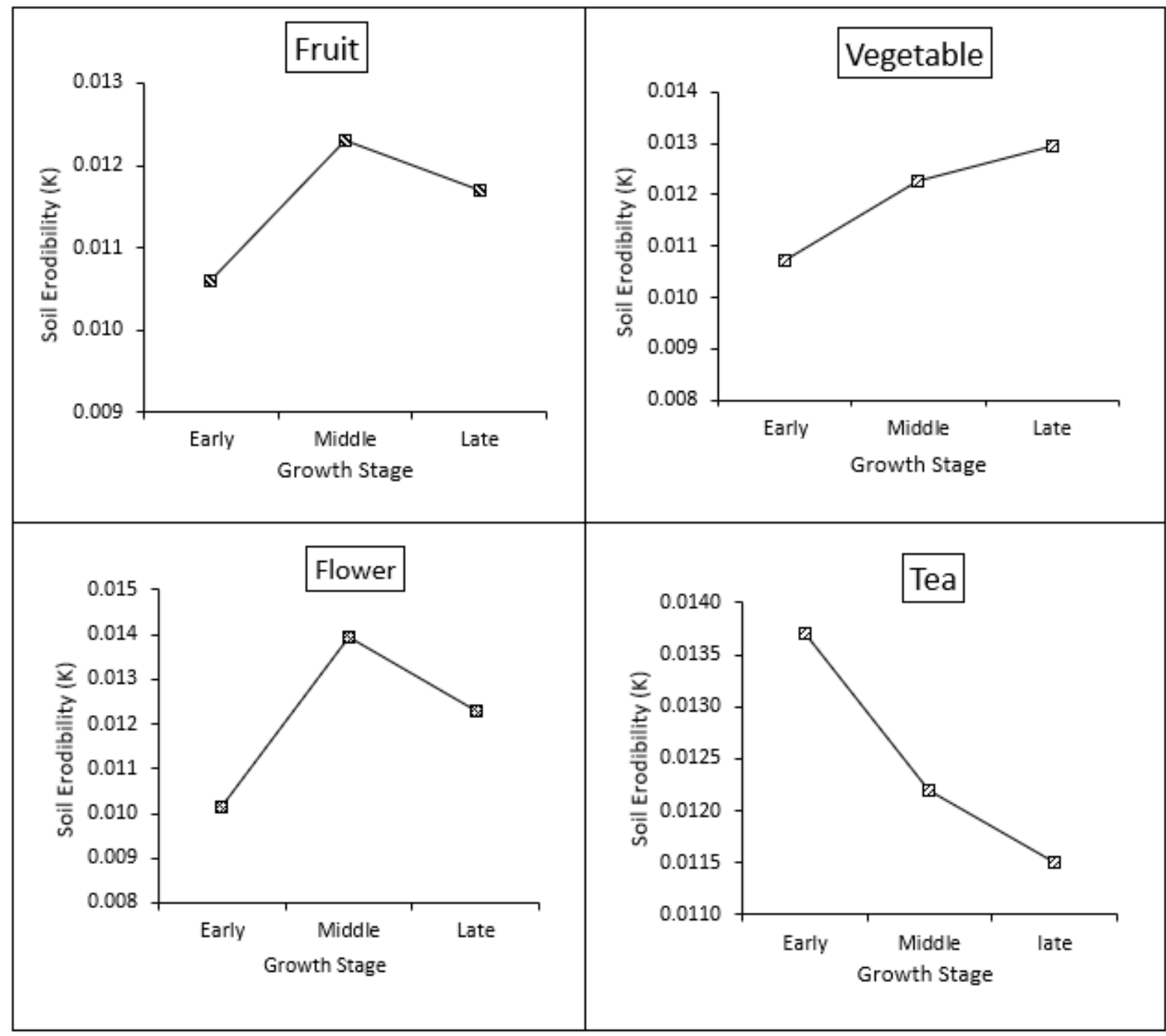

Fig. (4): Soil erodibility based on growth stages of fruit, vegetable, flower, and tea, crops.

\section{Spatial Erodibility Mapping.}

This study presents spatial variability of $\mathrm{K}$ values across surveyed farms in Cameron Highlands (Fig. 5). Based on the main types of crops being cultivated in the region, the soil variability mapping reveals areas with potentially high and low erodibility status. The $\mathrm{K}$ values ranged from 0.0084 (commonly occurred at forested regions) to 0.0161 which is observed in farms mostly dominated by shallow-root crops. Although the Cameron Highlands catchment is dominated by forest and the area farms. It is seen that lower part of the catchment is dominated with farms growing fruits and vegetable and thus, has high erodibility. Soil conservation measures should be deployed when cultivating those farms to minimized potential soil erosion. Similarly, sediment control structures such as silt traps should be placed to improve aggregate stability and avoid excessive soil displacement. 


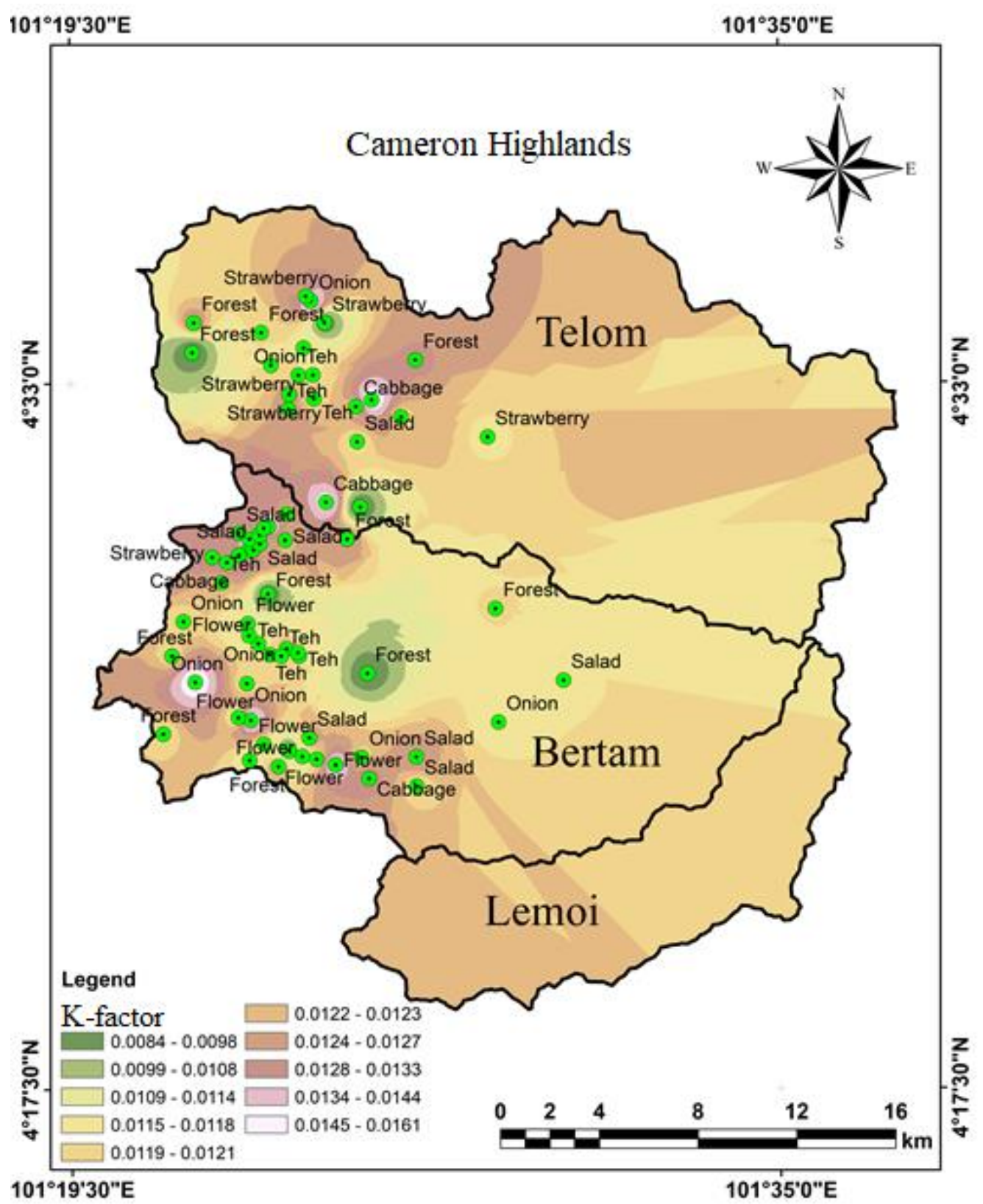

Fig. (5): Soil erodibility map of Cameron Highlands.

The spatial soil erodibility mapping shows that, Bertam catchment is most densely occupied with variety of agricultural crops and related farming activities. This could be the reason for high erodibility status of the soil which requires more attention for conservation measures. The relative areas of Telom, Bertam and Lemoi are 38\%, 43\% and $19 \%$ respectively. However, large sediment yield variations were computed by previous work. it was earlier provided by (Abdullah et al., 2019) that, Bertam catchment produced highest sediments (78.54 ton/ha/year) in Cameron Highlands followed by Telom with only 38.6 ton/ha/year, even though are approximately of the same size. This study provides an explanation for the reason of high sediment yields produced by Bertam catchment since similar climate and geology are found but with significant differences in 


\section{Nasidi et al./ Basrah J. Agric. Sci., 34(Special Issue 1): 41-53, 2021}

soil $\mathrm{K}$ factor.

Abdullah et al., (2019) computed potential soil erosion for the Cameron highlands and found that Bertam catchment produced more sediments than other two catchments. The possible reasons for this large variation was not earlier provided. However, this study supplies satisfactory explanation for the wide discrepancy since erosion is largely depends on soil $\mathrm{K}$ factor (Sadeghi \& Tavangar, 2015). Since, the area of entre catchment is relatively small and climate variation alone is unlikely to result into huge sediment yield variations. Moreover, the previous work used grossly approximated soil $\mathrm{K}$ factor which is too coarse to give detail of soil properties with high resolution.

\section{Conclusions}

This study conducted a spatial variability of assessment of soil erodibility (K-factor) in farming areas of Cameron Highlands. The work consisted of soil properties determination at cultivated area of the four major crops produced. It was found that the erodibility status is influenced by various farming operations at different growing stages and the peculiarity of each crop rootzone under consideration. This indicated a need that, the soil disturbance due to agricultural activities should be managed to achieve sustainable practices. Therefore, the developmental stage and type of a crop should be considered to estimate the soil $\mathrm{K}$ factor to avoid excessive soil loss due to erosion.

\section{Acknowledgement}

The authors would like to acknowledge Ministry of Higher Education (MOHE) and Universiti Putra Malaysia (UPM) for sponsoring this research under research number LRGS-NANOMITE/5526305. The supports from Bayero University, Kano, and Tertiary Education Trust Fund (TETFUND) are appreciated.

\section{References}

Abdullah, A. F., Wayayok, A., Nasidi, N. M., Hazari S. A. F, K., Sidek, L. M., \& Selamat, Z. (2019). Modelling Erosion and Landslides Induced by Faming Activities at Hilly Farms. Journal Teknologi, 6, 195-204.

ASAE. (2011). Standards for Engineering Practices and Data. Adopted and Published by American Society of Apicultural and Biological Engineers. 2nd. Edition.

Barbosa, R. S., Marques Júnior, J., Barrón, V., Martins Filho, M. V., Siqueira, D. S., Peluco, R. G., Camargo, L. A., \& Silva, L. S. (2019). Prediction and mapping of erodibility factors (USLE and WEPP) by magnetic susceptibility in basaltderived soils in north-eastern São Paulo state, Brazil. Environmental Earth Sciences, 78, 1-12. https://doi.org/10.1007/s12665-018-8015-0

Barrow, C. J., CLifton, J., CHan, C. W., \& TAn, Y. L. (2005). Sustainable Development in the Cameron Highlands, Malaysia. Journal of Environmental Management, $6, \quad 41-57$. http://journalarticle.ukm.my/2228/

Dabral, P. P., Baithuri, N., \& Pandey, A. (2008). Soil erosion assessment in a hilly catchment of North Eastern India using USLE, GIS and remote sensing. Water Resources Management. https://doi.org/10.1007/s11269-008-9253-9

Dantala, M. Z., Babangida, I., Ibrahim, A., Nasidi, N. M., Jafar, N. S., Mohammed, D., Muntaqqa, I., Usman, T., \& Ahmad, A. (2019). Effect of rice straw ash on soil properties and yield of cucumber. Algerian Journal of Engineering, 00, 34-52.

https://doi.org/http://dx.doi.org/10.5281/zenodo.35 53067

DID. (2012). Urban Stormwater Management Manual for Malaysia. In N. A. Zakaria, A. A. Ghani, \& C. K. Chang (Eds.), Manual 2nd edition. Kuala Lumpur, Malaysia All: Department of Irrigation and Drainage (DID) Malaysia.

Didoné, E. J., Minella, J. P. G., \& Evrard, O. (2017). Measuring and modelling soil erosion and 


\section{Nasidi et al./ Basrah J. Agric. Sci., 34(Special Issue 1): 41-53, 2021}

sediment yields in a large cultivated catchment under no-till of Southern Brazil. Soil and Tillage Research, 174, 24-33. https://doi.org/10.1016/j.still.2017.05.011

Diodato, N., Mao, L., Borrelli, P., Panagos, P., Fiorillo, F., \& Bellocchi, G. (2018). Climate-scale modelling of suspended sediment load in an Alpine catchment debris flow (Rio Cordonnortheastern Italy). Geomorphology, 309, 20-28. https://doi.org/10.1016/j.geomorph.2018.02.026

Fagbohun, B. J., Anifowose, A. Y. B., Odeyemi, C., Aladejana, O. O., \& Aladeboyeje, A. I. (2016). GIS-based estimation of soil erosion rates and identification of critical areas in Anambra subbasin, Nigeria. Modeling Earth Systems and Environment, $\quad 2, \quad 159$. https://doi.org/10.1007/s40808-016-0218-3

Ghani, A. H. A., Lihan, T., Rahim, S. A., Musthapha, M. A., Idris, W. M. R., \& Rahman, Z. A. (2013). Prediction of sedimentation using integration of RS, RUSLE model and GIS in Cameron Highlands, Pahang, Malaysia. AIP Conference Proceedings, 1571, 543-548. https://doi.org/10.1063/1.4858711

Ismail, H., Rowshon, M. K., Hin, L. S., Abdullah, A. F. B., \& Nasidi, N. M. (2020). Assessment of climate change impact on future streamflow at Bernam river basin Malaysia. IOP Conference Series: Earth and Environmental Science, 540, 012040. https://doi.org/10.1088/17551315/540/1/012040

Kaffashi, S., Radam, A., Shamsudin, M. N., Yacob, M. R., \& Nordin, N. H. (2015). Ecological conservation, ecotourism, and sustainable management: The case of Penang National Park. Forests, 6, 2345-2370. https://doi.org/10.3390/f6072345

Li, Z., Huang, J., Zeng, G., Nie, X., Ma, W., Yu, W., Guo, W., \& Zhang, J. (2013). Effect of Erosion on Productivity in Subtropical Red Soil Hilly Region: A Multi-Scale Spatio-Temporal Study by Simulated Rainfall. PLoS ONE, 8, 1-10. https://doi.org/10.1371/journal.pone.0077838

Mansor, N., Rashid, K. M., Mohamad, Z., \& Abdullah, Z. (2015). Agro Tourism Potential in Malaysia. International Academic Research Journal of Business and Technology, 1, 37-44. Retrieved from http://www.iarjournal.com/wpcontent/uploads/IBTC2015-p37-44.pdf
Minasny, B., Mcbratney, A. B., Mckenzie, N. J., \& Grundy, M. J. (2008). Predicting soil properties using pedotransfer functions and environmental correlation. Guidelines for Surveying Soil and Land Resources, 1983, 349-367. https://www.academia.edu/26921430/Predicting_s oil_properties_using_pedotransfer_functions_and_ environmental_correlation

Mispan, M. R., Haron, S. H., Ismail, B. S., Abd Rahman, N. F., Khalid, K., \& Abdul Rasid, M. Z. (2015). The Use of Pesticides in Agriculture Area, Cameron Highlands. International Journal of Scientific Progress and Research (IJSPR), 15, 1922. Retrieved from www.ijspr.com

Mohd-Ariffin, A. R., Md Ali, Z., Zainol, R., Rahman, S., Ang, K. H., \& Sabran, N. (2014). Sustainable Highland Development through Stakeholders' Perceptions on Agro EcoTourism in Cameron Highlands: A Preliminary Finding. SHS Web of Conferences, $\quad 12,01086$. https://doi.org/10.1051/shsconf/20141201086

Nasidi, N. M., Othman, M. K., Oyebode, M. A., Shanono, N. J., Zakari, M. D., Ibrahim, A., \& Shitu, A. (2014). Economic Viability for Reclaiming Irrigated Saline-Sodic Soil using Gypsum as an Amendment at Minjibir Irrigation Scheme, Kano. Red Sea University Journal of Basic and Applied Science, 2, 128-133. https://doi.org/10.11648/j.ijema.20140203.11

Nasidi, N. M., Wayayok, A., Abdullah, A. F., \& Kassim, M. S. M. (2020a). Spatio-temporal dynamics of rainfall erosivity due to climate change in Cameron Highlands, Malaysia. Modelling Earth Systems and Environment. https://doi.org/10.1007/s40808-020-00917-4

Nasidi, N. M., Wayayok, A., Abdullah, F. A., \& Kassim, M. S. M. (2020b). Vulnerability of Potential Soil Erosion and Risk Assessment at Hilly Farms using in SAR Technology. Algerian Journal of Engineering, 02, 44-58. https://doi.org/doi.org/10.5281/zenodo.3841100

Ostovari, Y., Ghorbani-Dashtaki, S., Bahrami, H. A., Naderi, M., Dematte, J. A. M., \& Kerry, R. (2016). Modification of the USLE K factor for soil erodibility assessment on calcareous soils in Iran. Geomorphology, 273, 385-395. https://doi.org/10.1016/j.geomorph.2016.08.003

Patowary, S., \& Sarma, A. K. (2018). GIS-Based Estimation of Soil Loss from Hilly Urban Area 
Nasidi et al./ Basrah J. Agric. Sci., 34(Special Issue 1): 41-53, 2021

Incorporating Hill Cut Factor into RUSLE. Water

Resources Management, 32, 3535-3547.

https://doi.org/10.1007/s11269-018-2006-5

Pradhan, B., Chaudhari, A., Adinarayana, J., \& Buchroithner, M. F. (2012). Soil erosion assessment and its correlation with landslide events using remote sensing data and GIS: A case study at Penang Island, Malaysia. Environmental Monitoring and Assessment, 184, 715-727. https://doi.org/10.1007/s10661-011-1996-8

Razali, A., Syed Ismail, S. N., Awang, S., Praveena, S. M., \& Zainal Abidin, E. (2018). Land use change in highland area and its impact on river water quality: a review of case studies in Malaysia. Ecological Processes, 7(1), 19. https://doi.org/10.1186/s13717-018-0126-8

Renard, K., Foster, G. R., Weeises, G. A., McCool, D. K., \& Yoder, D. C. (1997). Predicting Soil Reosion by Water: A guide to conservation planning with Revised Universal Soil Loss Equation (RUSLE), United Stated Department of Agriculture, Handbook, 703pp.

Sadeghi, S. H., \& Tavangar, S. (2015). Development of stational models for estimation of rainfall erosivity factor in different timescales. Natural Hazards, 77, 429-443. https://doi.org/10.1007/s11069-015-1608-y

Teh, S. H. (2011). Soil Erosion Modeling Using RUSLE and GIS on Cameron Highlands, Malaysia for Hydropower Development (Solborg at Nordurslod). Retrieved from https://www.engr.colostate.edu/ pierre/ce_old/Pro jects/linkfiles/Thesis Soo Huey Teh.pdf

Tew, K. H. (1999). Production of Malaysian soil erodibility nomograph in relation to soil erosion issues. Soil Erosion Research and Consultancy. 125pp.https://agris.fao.org/agrissearch/search.do?recordID=MY2014000388

Wayayok, A., Nasidi, N. M., \& Abdullahi, A. F. (2018). Erosion and sediment control guidelines for agricultural activities in Hilly Areas: Case Study of Cameron Highlands, Malaysia.

Weil, R., \& Brady, N. (2016). The Nature and Properties of Soils. In Tribology Series Fifteenth, 9, 59-101. https://linkinghub.elsevier.com/retrieve/pii/S0167 892208708435 . 